\title{
'Why Does This Make Me So Angry?': Using Self-Study to Uncover Hidden Epistemological Frames for Academic Identity Development
}

\section{Brianne Morettini \\ ORCID iD: https://orcid.org/0000-0002-8329-9866}

\section{Kathryn Luet \\ ORCID iD: $\underline{\text { https://orcid.org/000-0002-9449-7198 }}$}

\begin{abstract}
This study explores how two female-presenting tenured faculty navigate the tensions of engaging in scholarship while also being tapped to fulfil intensive service obligations to their respective academic departments. In this way, we use our everyday lived experiences as associate professors to examine social cohesion and our own processes of becoming in our fluid academic identities. The purposes of this study are to use self-study to 1) explore the informal education of non-scripted work for tenured faculty; and 2) to uncover hidden epistemological frames for understanding our academic identity that are left otherwise subdued in the patriarchal contexts of higher education. Using sensemaking theory and post-structural feminism to theoretically frame our exploration, two critical friends engaged in a form of intimate scholarship to explore their post-tenure experiences of resisting patriarchal institutional norms that subjugate women to service roles. This study demonstrates an ontological commitment to methodological inventiveness that recognizes and validates the emotive aspects of experience and being. Key findings include the need for more widespread realizations of how emotionally engaged research is a fruitful way to explore social cohesion in the context of higher education in that it may uncover subjugated aspects of self in academic identity development.
\end{abstract}


Keywords: academic identity development, self-study, critical friends, poststructural feminism

\section{Introduction}

In this study we enacted self-study methodology to deepen our understandings of academic identity development by exploring our social positioning as two female faculty members post-tenure. Specifically, we adopted a poststructural feminist lens to interpret our emotional responses to daily experiences and situations in our higher education contexts in order to make visible the intricacies of academic identity, emotions, gender, and power. To situate this work, which takes place in the north-eastern United States, we first describe our context and the genesis of our exploration.

The fall semester of 2017 brought great professional joy to us as we were notified that our university had granted us tenure with promotion to the rank of Associate Professor. Working at an institution in the U.S. that now has R2 Carnegie classification, we were both proud and humbled that our research as teacher educators was deemed rigorous and significant enough to earn tenure with promotion. Since we both completed $\mathrm{PhD}$ programs at research-intensive institutions elsewhere in the U.S., we admittedly felt relatively prepared for the challenges and rigors of tenure-track life. Further, as former classroom teachers, we also felt relatively prepared for teaching in the higher education context of educator preparation. Like many of our colleagues across the world, we found the service requirements to be the more pernicious and demanding aspect of our work as post-tenured faculty. While we understood the expectations of tenure, we felt confused and conflicted about how to reconcile the increased and intensified service demands alongside our continued research agendas. This tension is where the study began to unfold.

This study, therefore, explored how two tenured female faculty experience and navigate the 'living contradictions' (Pinnegar \& Hamilton 2009:182) and tensions (Berry 2007) of teacher education faculty who understand, appreciate, and enjoy scholarly activity but who have also been tapped to fulfil intensive service obligations to their respective academic departments and colleges. The purpose of this study was to explore the informal education of non-scripted work for tenured faculty as a significant influence on our academic identities. We also adopted a post-structural feminist lens 
to analyse our experiences as critical friends in a self-study to uncover epistemological frames that are otherwise left hidden in the masculine contexts of higher education (Pinar 2007).

Using self-study methodology, we made sense of our developing and changing - academic identities and social cohesion with each other through the ways we fulfil our felt obligations to students, colleagues, and our profession, while at the same time identifying what we find contradictory to our work as educational researchers. The term 'social cohesion' has multiple definitions. We conceptualized social cohesion as the webbing that secures us in a particular context, enabling our shared sense of being 'engaged in a common enterprise, facing shared challenges' as 'members of the same community' (Maxwell 1998:ix). In sum, we turned to more scholarly and productive ways to make sense of our post-tenure experiences and how they were (re)shaping and influencing our academic identities, particularly related to what we perceived as a very gendered imbalance to increased service demands post-tenure. So, the research questions, that grounded this work were:

- What institutional norms and expectations create internal tension and why?

- What happens (to us) when we push back and resist institutional norms and expectations?

- How does understanding our emotional responses to tensions influence our academic identity development post-tenure?

We explored these questions using a self-study methodology framed by sensemaking theory, post-structural feminism, and queer theory.

\section{Theoretical Frames}

This study demonstrates an ontological commitment to understanding a social world that recognizes and validates the emotive aspects of experience and becoming. In theoretically framing our work; therefore, we consulted literature on sensemaking, post-structural feminism, and queer theory to guide the study as well as the modes of inquiry and analysis.

\subsection{Sensemaking}

Sensemaking can be broadly understood as the narrative or mental map(s) 
that people create in order to render meaning from their experiences and to use untenable situations as prompts to action (Powell \& Colyas 2008; Weick 1995). Sensemaking, therefore, refers to how individuals 'notice, select, and interpret ideas in their environment, but also how they enact them so as to be rendered meaningful' (Rom \& Eyal 2019:63). While working towards tenure for almost six years, we constructed academic identities as educational researchers; our sensemaking schemas supported and affirmed our academic identities as researchers when we received tenure with promotion. However, our identities as researchers became incongruent with our institution's posttenure expectations around service.

As such, we sought ways to make sense of our new identities by engaging in what others (Aula \& Mantere 2013; Pratt 2000) describe as sense breaking, or rupturing from previous sensemaking narratives around identity. We turned to sensemaking as a theoretical frame because it acknowledges how individuals 'rely on sensemaking to navigate organizational dynamics and to address professional issues' (Rom \& Eyal 2019:63). Sensemaking, therefore, framed how we grappled with the dissonance we experienced between our former roles as researchers and our new perceived roles as service purveyors.

\subsection{Post-structural Feminism and Queer Theory}

Similar to extant self-studies (see also Strom \& Martin 2013; Abrams et al. 2012) we used a feminist post-structural or postmodern approach (St. Pierre, 2000) focused on identity and being a teacher educator to explore and unpack our perspectives and experiences in the patriarchal systems of the academy and in educational research that encourages us to bracket rather than emphasize our emotions. Post-structural feminism is a lens that disrupts hierarchical ways of viewing the world and instead emphasizes 'relational ways of viewing the world' (Strom et al. 2014:32). Further, post-structural feminism allows for more discursive notions of identity, a process of becoming who we are not yet through new levels of awareness (Strom et al. 2014), In particular, through a post-structural feminist frame, we positioned our emotions and feelings as epistemologically legitimate dimensions of our identity development as we made sense of our post-tenure experiences as a way to defy the subjugation of emotions and the rupture between feeling and knowing (Forgasz \& Clemans 2014). In the study, therefore, we honoured 
emotions as valid and valuable epistemological sources of knowledge.

While we used post-structural feminist theory to reposition our identity development from a strength-based perspective, we used queer theory to help us problematize and destabilize the gendered identities we have attributed to ourselves and to others. Queer theory, therefore, pushed us to consider how our gendered identities might be more fluid and not 'construed as a stable identity' (Butler 1999:365). Together, post-structural feminist theory allowed us to place our more hidden and emotional aspects of self on the same plane as our professional aspects of self, while queer theory helped us to reconsider how socially constructed notions of gender shaped our interpretations of self and influenced our identity development. Extending from the post-structural feminist and queer theory frames of this study, we acknowledged the collaborative nature of self-study (Taylor et al. 2006) and the ways in which self-study impacts not only ourselves but also our colleagues (Taylor \& Coia 2014).

Indeed, our emotions offer 'a legitimate way of knowing' (Lawrence 2012:63). We attend to our emotions and personal perspectives because of the 'political act they symbolize' (Lawrence 2012: 77). This study centred feelings and emotions as a legitimate way to better understand academic identity development as both fluid and dynamic. Through this study, therefore, we took up the call to find opportunities to 'disrupt our own ways of knowing' (LaBoskey 2004:824) and move away from positivist notions of research and objectivist epistemological sources of knowledge.

Through these frames, we acknowledge that in our lives as researchers, we have experienced 'a culture dominated by an ideology of professionalism ... embedded in an objective stance and rationality perpetuated through patriarchy' (Kuzmic 2014:78). With the encouragement of extant research (see also Kuzmic 2014; Davies 2010; Luttrell 2003; Campbell 2002; Stanley \& Wise 1993; Jaggar 1989), we sought to explore our emotions as worthy ontological aspects of how we understand our social world.

\section{Modes of Inquiry}

Building on the notion of intimate scholarship (Hamilton \& Pinnegar 2015), we discussed ways to explore and inquire into our post-tenure experiences and the emotions and tensions surrounding those experiences. Since a 
predetermined methodological standard for self-study does not exist, we consulted the methodological considerations for self-study (LaBoskey 2004) in conjunction with seminal readings (see also Pinnegar \& Hamilton 2009; Samaras \& Freese 2006) on self-study to frame our work. Specifically, selfstudy is improvement oriented; draws on interactions with colleagues and educational research; engages multiple qualitative methods; and prompts us to disseminate our work to the larger scholarly community (LaBoskey 2004).

We used self-study methodology to enact agency by centring our experiences and related emotions as valuable and worthy epistemological sources of knowledge. Specifically, since we as female post-tenured faculty have been asked to shoulder the bulk of the service obligations in our respective departments, we are engaging in resistance by using our experiences - both emotive and cognitive - to make sense of and render meaning from our experiences to contribute to and extend what we know about social cohesion and academic identity development.

Our self-study methodology, then, honours how our shared sense of purpose enhanced our feelings of contextual investment and belongingness with one another. By disseminating this work, we stand with others who might experience tensions in their own academic identity related to the competing demands placed on their time. With a nod to such solidarity, the specific methods we used to engage in this study are critical friends and dialogue as we acknowledge that this research involves interactions situated in particular spaces, both contextual and temporal.

\subsection{Critical Friends}

As self-study researchers, we value 'a commitment to outside interpretations and a willingness to review one's existing frames' (Samaras \& Freese 2006:49). Since we both came to this work with the strong social cohesive of female friendship through knowing each other for several years and working, among other roles, as Co-PIs on a research grant, co-authors on presentations and publications, and by becoming recent mothers of young children, we felt the connectedness and cohesion necessary to serve as critical friends to one another.

Towards the end of the 2018-19 academic year, we dedicated the time to explore our tensions and emotions by making sense of how our reactions to certain things could shed light on our changing academic 
identities. We decided to keep electronic journals to document particular moments denoted by resistance, confusion, surprise, or even affirmation. We had access to each other's journals at all times and used them as spaces to document our feelings and to comment on each other's experiences. We commented on each other's journals several times each week and then met every other week to consider different dimensions of our experience: What did we learn about each other? What did we learn about ourselves? What are we learning about how our roles shaped ourselves and how our 'selves' shape our new roles? In doing so, we problematized researcher positionality in selfstudy through this work as critical friends.

Further, we created a way to both meaningfully navigate and explore the influence of gender stereotypes and expectations on our post-tenure experiences. Specifically, moving from friends to critical friends enabled us to shift our frequent conversations from so-called venting sessions to more focused discussions of what we observed as the very gendered institutional norms and expectations in which our colleagues and context seemed so entrenched. For example, we began to discuss the overarching research questions with an eye toward the relationship between gender, agency, and power.

Indeed, gender shapes how we see the world (Thomas \& Beauchamp 2010), but can we use our insights and solidarity as critical friends to reshape how we see ourselves and our academic identities? If we saw ourselves as more agentive, would we advocate more for ourselves in certain situations? Moreover, why do we feel that we can only share our feelings and emote to each other? These sorts of wonderings arose from informal conversations through our years of friendship; this study represents our attempt to formalize our efforts for public critique and consumption. In this way, we centre our experiences and resultant emotions as epistemologically worthy, meaningful, and scholarly.

\section{Data Sources}

Each week we would take to our journals to write about administrative mandates related to service that caused personal tension and, quite frankly, annoyance. Every couple of days, we would read each other's journal entries and respond in affirming ways about our perspectives and how we felt about what we were being asked to do. 


\subsection{Weekly Journals}

The weekly journals demonstrate our shared epistemological commitment to the collaborative construction of knowledge, which in this case, stems from reflexive or autobiographical methods of self-study. To engage in self-study is to know and write narratively. Narrative truth (Bruner 1986) should clearly illustrate significance. When a narrative is finished, 'it should be unthinkable for a bystander to say, "So what?"' (Labov 1997:366). Like other self-study researchers (see also Berry 2007), we explored the self through documenting a series of tensions related to our positionality in the academy. By taking the time to journal each week - sometimes several times a week - the researchers maintain that our ongoing academic identity development as teacher educators is rooted in understanding personal-professional connections. To this point, Cole and Knowles (2000:15) write that 'making sense of prior and current life experiences in the context of the personal as it influences the 'professional' is the essence of professional development'.

Coupled with an understanding of the importance of ongoing professional development rooted in understanding self is the idea that teaching is autobiographical work in which the teacher must first know oneself (Cole \& Knowles 2000). Since context shapes and influences the nature of our work as teacher educators, it is important for us to explore who we become, both personally and professionally, when faced with the tension of post-tenure service commitments in our professional context. With this in mind, we have a particular lens on the 'political and social' (Cole \& Knowles 2000:14) conditions and events that shape who we are what we perceive to be a patriarchal context.

Positioning ourselves as critical friends allowed us to take up the call to nourish the reflections that ultimately lead to 'heightened awareness, change, growth and improvement of self and our profession' (Ryan 2005:4) as documented through our journals and our critique of each other's journals as critical friends.

We engaged in two cycles of data analysis. In the first cycle of analysis, we read the entire corpus of data, which comprised all journal entries and critical friends' comments. Next, we engaged in initial coding procedures (Charmaz 2014; 2006; Corbin \& Strauss 2008), going through the data line by line. After initial codes had been developed, we engaged in second-level analysis with a specific interest on emotion coding (Prus 1996; Goleman 1995). 


\section{Generative Findings}

We generated nine codes in the first level of analysis. In the second level of analysis, we looked for relationships and themes between and among the nine codes. We then created the three final themes from our iterative interactions and analyses.

\subsection{Emotion as a Valid Analytic Tool}

We interpreted our data to show that an emotional response to an event served as a signal to underlying inequitable structures and practices at our institution. Inequitable structures triggered emotions of frustration and anger because such structures and practices assume the subjugation of women in our setting. For instance, in one entry, Author 2 described a meeting in which she 'did not hide [her] frustration/irritation at the nature of the conversation' in which she felt a co-worker addressed her in a condescending manner, and she worried that her colleagues found her reaction impolite (Journal entry, 5/10/19). In response, Author 1 replied, 'You should be allowed to emote during frustrating moments' (Journal reply, 5/21/19). This exchange showed that we were at times more worried that colleagues would perceive us as too emotional or as unprofessional rather than acknowledging the underlying inequities that were triggering such emotional responses from us. This example also illustrated how emotion became a lens through which we learned more about ourselves and more about each other. To that point, we began to validate and legitimize our emotional responses to situations, which allowed us to understand how such responses indeed stemmed from our feelings of subjugation as women.

In another instance, Author 1 wrote:

A few weeks ago, I was sitting in a meeting with some junior faculty from my department, and I found myself wildly jealous of them. Even though being tenure-track is incredibly stressful, I actually feel like I was more protected than I am now. I was tenured about 18 months ago, so this academic year was my first year as a tenured Associate Professor. I'm not sure what I thought would be different, but I certainly didn't think I would feel busier, more stressed, and somehow invisible the way I do now (Journal Entry, 5/4/19). 
In response to this description of feeling 'somehow invisible' in my post-tenure positionality, Author 2 responded, 'this is a good descriptor that I hadn't thought of before ...' (Journal reply, 5/10/19). Such emotional solidarity made us feel more complete in who are as female academics in the patriarchal context of higher education. In using post-structural feminism and queer theory, we centred our gendered identities and actually began to honour and validate our emotions as tools we used to navigate a patriarchal context. In addition, from a journal entry dated May 8, 2019, Author 1 began to articulate some frustrations around the perceived surveillance and micromanagement of her work. Here, I wrote:

As a tenured faculty member who has taken on service responsibilities but who also sees scholarly productivity as an integral part of my professional duties, I get frustrated that our administrators feel the need to micro-manage our time after the end of the semester and fail to see the value of scholarly contributions for tenured faculty. Since I view scholarly productivity as integral to my professional responsibilities, I think it is something I should work on as part of my weekly work. Put differently, I shouldn't have to wait until I'm off the clock to get some writing done.

In response, Author 2 wrote, 'Exactly! Why is it assumed that we no longer have anything important to say through our scholarly contributions?' (Journal reply, 5/9/19). By acknowledging our emotional reactions to events and experiences, we were able to see each other and ourselves as more complete in that our efforts to bifurcate our emotions from our academic identities were unnecessary and superficial. Our acknowledgement of each other's feelings validated our own feelings as valid and valuable, which made us feel whole. In this way, we began to legitimize a more authentic academic identity through our work together. Further, as critical friends engaged in this exploration together, we were able to strengthen our social cohesion with each other by affirming our shared feelings and emotional responses to situations in our context. Building on that insight, below is an excerpt from Author 1's journal when she describes her decision to step down from a large service role in her department:

I made the decision to step down as program coordinator after this 
current academic year, which we have been consistently reminded does not end until June 30. I thought I would feel relieved about this decision, but I worry that I'm letting people down-my department colleagues, my critical friend, and even the Dean's office who have entrusted me with ushering in this program to our college and community college partners. Right now, our department is still searching for someone to coordinate the program. I guess I'll just have to see what happens over the summer (Journal entry, 6/6/19).

In acknowledgment and validation of my feelings around this decisionwhich were primarily guilt and self-loathing-Author 2's response below shows how we affirmed each other's feelings:

You're not letting me down! How else could you look at the decision in a more positive light? Maybe you could say that you're making a commitment to being happier/ healthier - and that by being happier/ healthier you will be better equipped to be there for your family and your friends (and colleagues!). Or that you will be able to be a more dedicated researcher, so you'll be helping teachers in the field. Maybe we need to think of some strategies to view our decisions through a lens that that doesn't involve guilt! (Journal response, $6 / 10 / 19)$.

The above exchange shows that as critical friends we supported each other in realizing a more complete, fuller academic identity that centres - rather than represses - our feelings and emotional responses. The data also show that emotions are valid indicators of our self-efficacy and agency within our particular context. Further, Author 2 wrote, 'In a lot of respects, it comes down to a matter of time. I am so overwhelmed with tasks that it sure seems easier to work within the rules than to try to change them' (Journal entry, 6/10/19). In solidarity, Author 1 wrote, 'the tasks don't draw on our skill sets that we worked very hard to cultivate and refine in order to have a tenured/ tenure-track position in the first place' (Journal response, $6 / 11 / 19)$.

\subsection{Situating Gender as a Heuristic}

At various times in the data, we questioned how our gender might have 
influenced certain situations or our perceptions of those situations. In particular, we wondered whether men would be treated the same way as we were in certain exchanges and whether men would experience the same sense of guilt from having an emotional response to a situation. For instance, after recounting her sense of resignation related to the scope of her responsibilities as a program coordinator, Author 1 asked, 'But, how would a man have handled [these responsibilities]? Would a man simply have refused? Would a man have been more direct and said something straight to the administrators?' (Journal entry, 5/22/19). Our post-structural feminism and queer theory frames prompted us to consider the role our gender played in others' expectations of us. As women, we were expected to appease others by shouldering massive amounts of service while at the same time appearing compliant and agreeable.

Our analyses showed us that we both felt a strong sense of guilt for even beginning to question institutional norms and practices, despite the inequities we both perceived in such norms and practices due to the gendered imbalance of service expectations. Indeed, we both felt that because we are women, that we were expected to shoulder the burden of responsibility for the programs we were coordinating while remaining quiet about more equitable and expeditious ways to serve our students. For example, in the excerpt below from Author 2, she reflects upon a critical incident in which she voiced frustration to an advisor for her program:

Since its Spring and we're looking ahead to Fall, I've been asked to start attending meetings and making decisions, taking on some of the responsibilities ahead of time with none of the release time, given that I will officially begin coordinating this program next fall semester. Also, I'm taking on these responsibilities while missing some of the context because I haven't coordinated in two years. So, I'm trying to figure out my way back in, but as I'm doing so, I feel a growing impatience from colleagues who have been working on particular issues for the last couple of years. For example, in dealing with one issue, I tried to step in to propose a solution/compromise (and to get the meeting back on track - we hadn't even gotten to item 1 on the agenda) I was met with a lot of hostility from one participant who suggested I didn't appreciate how complex her work is, and another participant kind of just 
ignored me. All the while, the current coordinator was 'running' the meeting without saying anything. I wonder if he had said anything if the participants would have reacted with such hostility. He's an older male. I hadn't even thought of that before, but after reading Author 1's journal this week, I wonder if there are ways in which my gender impact how people treat me in the role of coordinator (Author 2, Journal entry, 5/10/19).

Again, in direct response to this journal entry, Author 1 affirmed and validated Author 2's insights about some implicit gender bias playing out in this situation. Here, she responded,

'But, no! You should be allowed to emote during frustrating moments! We should not have to bury our emotions. And, I agree with you also - I don't think the participant would have reacted to an older male the same way' (Author 1, Journal response, $5 / 21 / 19)$.

This exchange demonstrates how we validated each other's emotional responses to events and leveraged our social cohesion as critical friends to affirm the gendered inequities we were each experiencing.

In addition to the ways we questioned the role gender played in others' perceptions of us, we both questioned implicit gender bias in the assignment of these service roles. To that point, in a journal entry Author 1 wrote:

The majority of tenured faculty who also serve as program coordinators are women, even though there are several tenured faculty who are males. What is behind the gendered imbalance of service at my institution? Is that because more women are asked to do service? Is it because more men say no to service without fear of letting anyone down or feeling guilty? (Journal entry, 5/18/19).

Another example of situating gender as a heuristic appeared in a journal entry from a few days later in which Author 1 wrote:

The work of program coordination keeps seeming to expand and 
broaden. Earlier this week, for example, I got an email from an administrator asking me for a headcount of individuals I work with who were planning to attend the 6-hour retreat she was hosting. Evidently she needed the headcount for lunch. So, it seems like last week I found out that I am in charge of marketing, this week I'm an event planner and personal assistant, and I'm now left wondering what next week will reveal to me. And, I'm still left wondering if she would have asked a man to complete this seemingly menial task for her (Journal entry, 5/21/19).

In response to this piece of my entry, Author 2 responded, 'So frustrating to do what a Google form could do effectively' (Journal response, $6 / 10 / 19)$. The critical friend's response to frustration over a seemingly menial task - and the larger question of the gendered role it played validated our feelings of annoyance at not just the nature of our new roles but with the gendered imbalance of expectations they seemed to communicate to us.

In another example of how we situated gender as a heuristic for understanding and acknowledging our academic identity development, Author 1 wrote:

I realize that my ire toward the scope of the role has caused me to appear as a version of myself (e.i.o) that I dislike; I'm angry at work, I dread checking my emails; and I'm becoming more vocal at work about my ire toward the administrators. I don't like how this makes me feel and I don't like how this makes me appear, which seems to be too emotional. But, how would a man have handled this situation? Would a man simply have refused? Would a man have been more direct and said something straight to the administrators? Would a man appear less emotional and hence more professional? Would a man be taken more seriously because of that? (Journal entry, $5 / 22 / 19)$.

\subsection{Questioning as a Way to Foster a Fuller Sense of Self}

The data also revealed that we were beginning to use questions in our journals to further our own sense of self and identity development; more 
specifically, questions became a way for us to push our own thinking and consider our positionality as tenured female faculty. Questions spanned a wide variety of topics, and though often posed rhetorically, these questions came to represent genuine queries about why we felt compelled to delegitimize our emotional responses in the first place. The excerpts below highlight some of the questions we asked ourselves and each other related to our sensemaking around academic identity development. In this first excerpt from Author 1, shown below, I question the idea of how to reconcile my newfound workload of service obligations with my academic identity as a researcher:

I recently received a message that since all faculty are on contract through June 30, we are all expected (e.i.o) to attend the late-June workshops that the administrators are facilitating. I actually become enraged when I try to reconcile in my mind the expectations for research for an R2 institution and the excessive service expectations for tenured faculty. Shouldn't our administrators respect the fact that - in addition to meeting all the demands of service - a that we still need time for research, to develop studies, to read literature, to collaborate and provide and receive feedback on manuscripts? When am I actually supposed to do all of this? Shouldn't this be considered central to my role as an Associate Professor? (Author 1, Journal entry, 5/4/19).

Likewise, Author 2 calls into question how being tenured has, in some ways, made her more worried or 'paranoid' about others' perceptions of her. Here, she explains:

This year, in particular, it's been difficult to watch newly hired tenure track faculty start with much lower course loads (2/2!) and almost no expectations for service. I suppose some questions to consider are: Why do I care so much what these people think of me? Could I have published more if I didn't have so much service, or was that an excuse? Also, what is my place in the institution as a newly-tenured faculty member? Should I be taking up more service? Trying to publish more? Applying for grants? This year, as a new mom, I've just been trying to survive, but I think next year I have to push myself a little harder (Author 2, Journal entry, 5/3/19). 
In direct response to Author 2's question of 'what is my place in the institution?' Author 1 wrote, 'I wrote about something similar. My entry was filled with a lot of emotion. Moreover, for some reason, I felt I could not - or should not - write with so much feeling. Why is that?' (Author 1, Journal response, 5/4/19). This critical friends' exchange nurtured our changing academic identities as tenured faculty inasmuch as it provided us with a temporal and physical space to even pose the questions in the first place. Then, having a dedicated space to question and to receive affirmation and responses to those very questions fostered our identity development and allowed us to become more fully aware of the influences on our academic identity development in the post-tenure context of higher education.

As we continued to question our situated identities, we began to wonder about each other's perceptions of us and how that could influence our perceptions of self. For example, Author 2 wrote:

I would hate to come across as being unappreciative to have a tenured position, even with the headaches that come along with it. On the other hand, I think I'm not complaining for the sake of complaining, but it does seem like a lot of the stuff we're writing about does make it hard to do our core job effectively. So, how can we look critically at our job responsibilities/expectations without seeming ungrateful? Also, I suppose another question I have is: Is it even possible to change institutional norms/expectations? Would it make more sense to think about how to better navigate within them rather than changing them? I wonder if I need to look more at myself and less at the institution...that is, should I try to change the way I respond to things, rather than the things I'm responding to? (Journal entry, 6/10/19).

In response to this particular entry, Author 1 responded, 'At our department retreat yesterday, we talked about the difference between complaining and inquiring, and I think that is a powerful way to affirm our reactions' (Journal response, 6/11/19). This theme in the data illustrates that we both continued to question how we would be perceived by others, as we were fearful of being seen as noncompliant and irascible, fear that is an extension of very patriarchal constructs for feminine behaviour. In this way, 
our context and the demands being placed upon us influenced our sense of self as researchers.

\section{Discussion}

From the iterative analysis, we generated three central themes: emotion as a valid analytic tool; gender as a heuristic; and the importance of questioning as a way to foster a fuller sense of self. Together, these themes can be used to shed light on the research questions we used to guide our study. For example, the institutional norms/expectations that created the most salient internal tensions for us was our perception that colleagues thought we, as tenured female faculty, ought to shoulder the burden of service demands of our respective departments. In our journals we each wrestled with this tension: how to present ourselves as appreciative of our tenured positions by meeting these service demands but at the same time wondering why we felt we needed to act demure and appreciative in the first place. Post-structural feminism and queer theory prompted us to explore our emotional responses to situations; we were then able to see the very gendered notions of identity that were driving our thinking around how we should present ourselves and how others ought to perceive us. To that end, we used sensemaking theory to validate our frustrations and affirm the patriarchal context that we were trying to navigate.

With respect to the second research question regarding what happens to us when we push back and resist institutional norms and expectations, we found that working as critical friends in our push back allowed us to develop academic identities that felt truer to what we wanted for ourselves - the time and space to engage in meaningful research, teaching, and service and to position ourselves as worthy of the boundaries we wanted to establish between these aspects of our careers. To be frank, it felt good to have a safe space to voice frustrations about the tedium of the tasks we were being asked to complete. Many of the tasks we were asked to complete felt demeaning and in stark contrast to the identities we had developed that centred our skills set as social scientists. In our new roles as tenured faculty, we found that pushing back and resisting institutional norms and expectations that felt very gendered and patriarchal affirmed our identities and took back some control over the nature of our daily lives in academia. We also hope our resistance to patriarchy sent a message to other female faculty that they are well within 
their rights to self-advocate for an academic identity that aligns more closely with their passions and skills and does not position them as less capable or esteemed than their male counterparts.

In response to our third and final research question, how understanding our emotional responses to tensions influences our academic identity development post-tenure, we found that since we often had very similar emotional responses to our felt tensions, such as guilt and worry, that our emotional responses remain valid signals of deeper inequities in situations and circumstances we were encountering. Indeed, our study shows how we internalized patriarchy by even questioning the validity of our emotions in the first place. In this way, our work builds on prior work (see also Kuzmic 2014; Taylor \& Coia 2014; Campbell 2002; Jaggar 1989) focused on epistemology, emotions, and gender. Emotional responses, rather, should be recast as valid epistemological frames. To this point, our work adds to what we know about the relationship between epistemology, emotions, and academic identity:

As well as motivating critical research, outlaw emotions may also enable us to perceive the world differently from its portrayal in conventional descriptions. They may provide the first indications that something is wrong with the way alleged facts have been construed, with accepted understandings of how things are (Jaggar 1989:161).

Female faculty, in particular, should resist the 'emotional labor' (Taylor \& Coia 2014:16) associated with the urge to bury emotions in an effort to act more professional - according to patriarchal norms - and listen to and embrace their emotions and use those emotions as a guide for action. In this way, our own academic identities now feel less encumbered by external and patriarchal standards and expectations because we recognize ourselves as the experts of our experiences and embrace the validity, legitimacy, and importance of our emotions as tools to guide our thinking, our acting, and our being in academia.

In the past three years, we have encountered the environmental turbulence of our institution's increased expectations for service for posttenured faculty; in particular, it seems that the bulk of the service is achieved by women (Misra et al. 2011). Given the recent worldwide shift to virtual 
learning and working from home due to the COVID-19 global pandemic, the notion of mother-scholaring (Matias 2011) remains a poignant way for women to make sense of the competing and intensified demands on their time. By centring our experiences and emotions, we drew on each other as critical friends within a self-study to resist the patriarchal expectations of the academy (Pinar 2007) and uncovered the ways in which we resisted the unlearning of our academic identities as researcher, despite the messages we received about the expectations of our career trajectories post-tenure.

In their work on framing self-esteem, Butler and Branyon (2020:154) write, 'Task perception is intricately interwoven with job motivation'. To that end, this study is an existential exploration of who we are and how our academic identities are shaped by certain demands in context. Through a self-study methodology, we made sense of how our own lived experiences guided our actions, considering our felt obligations to self and to students, both our students and our students' future students. Like other studies (see also Griffiths et al. 2004) this study also sought to situate gender as part of the larger landscape of social justice. By centring our perspectives and associated emotions as legitimate epistemological sources of knowledge and understanding (Forgasz \& Clemans 2014), we 'pay attention to ... gender ... power, perspective, voice, and self-respect' (Griffiths et al. 2004:685) and realize the possibilities of emotionally engaged research by acknowledging the epistemological worth and value of emotions as an important resource (Kuzmic 2014; Campbell 2002).

\section{Conclusion}

The study explored how we modified ourselves through this experience. As newly tenured faculty and new mothers, we experienced constant role negotiation in both our personal and professional lives. We developed learnings from our emotional reactions that illustrate the ways we made sense of our experiences as framed through our work as critical friends; through this study we endeavoured to actively resist the unlearning of our researcher identities. We set out to do this work, in part, as an effort to increase our social cohesion with each, thereby enabling a greater sense of belongingness in our institution. Initially, we approached this work with the assumption that we ought to find a safe space to share thoughts and feelings in order to bracket them and set them aside so as to appear more professional and to 
project - what we previously thought would be - a more legitimate academic identity. However, after some time engaging in this work, we realized that our emotional responses to situations and events ought to be centred and shared as valid epistemological sources. Emotionally engaged research, therefore, is a fruitful and valid way to enact social cohesion in the context of higher education in that it can uncover subjugated and hidden aspects of self in academic identity development.

Indeed, we need to articulate what all of these concepts mean in the context of our work related to academic identity development; this is our obligation as self-study scholars. Using sensemaking, post-structural feminism, and queer theory to frame this study, two critical friends engaged in a form of intimate scholarship to explore their post-tenure experiences and to remain connected to what we understand as the larger purpose and vision of teacher education. In this way, we enacted social cohesion with the call for reconnection and collaboration. This study suggests the need for more widespread realizations of how emotionally engaged research is a fruitful way to explore social cohesion in the context of higher education in that it may uncover subjugated aspects of self in academic identity development. Now, we urge colleagues to resist the patriarchal institutional norms and expectations they might encounter by centring their emotions as valid and reliable analytic tools and epistemological frames.

\section{References}

Abrams, L., R. Abi-Hanna, N. Bess, M. Collucci, C. Dacey, J. Dauplaise, S. Mastellone, K. Strom \& M. Taylor 2012. 'I am what I am not yet': Becoming Teacher Educators and Change Agents. In Erickson, L.B., J. Young \& S. Pinnegar (eds): Extending Inquiry Communities: Illuminating Teacher Education through Self-Study. Proceedings of the $9^{\text {th }}$ International Conference on Self-Study of Teacher Education Practices. Provo, Utah: Brigham Young University.

Aula, P. \& S. Mantere 2013. Making and Breaking Sense: An Inquiry into the Reputation Change. Journal of Organizational Change Management 26,2: 340 - 352. https://doi.org/10.1108/09534811311328380

Author 1 2019. Journal Entry. Personal Communication.

Author 1 2019. Journal Response. Personal Communication. Author 2 2019. Journal Entry. Personal Communication. 
Author 22019 Journal Response. Personal Communication.

Berry, A. 2007. Tensions in Teaching about Teaching: Understanding Practice as a Teacher Educator. Dordrecht, The Netherlands: Springer. https://doi.org/10.1007/1-4020-5993-0

Bruner, J. 1986. Actual Minds, Possible Worlds. Cambridge, MA: Harvard University Press. https://doi.org/10.4159/9780674029019

Butler, J. 1999. From Interiority to Gender Performatives. In Cleto, F. (ed.): Camp: Queer Aesthetics and the Performing Subject: A Reader. Ann Arbor, Michigan: The University of Michigan Press.

Butler, B. \& A. Branyon 2020. Who Does Self-Study and Why? In Kitchen, J., A. Berry, S. Bullock, A. Crowe, M. Taylor, H. Guojonsdottir \& L. Thomas (eds.): International Handbook of Self-Study of Teaching and Teacher Education Practices. $2^{\text {nd }}$ Edition. The Netherlands: Springer. https://doi.org/10.1007/978-981-13-6880-6_5

Campbell, R. 2002. Emotionally Involved: The Impact of Researching Rape.

New York: Routledge.

Charmaz, K. 2006. Constructing Grounded Theory: Methods for the $21^{\text {st }}$ Century. United Kingdom: Sage.

Charmaz, K. 2014. Constructing Grounded Theory. $2^{\text {nd }}$ Edition. United Kingdom: Sage.

Cole, A.L. \& J.G. Knowles 2000. Researching Teaching: Exploring Teacher Development through Reflexive Inquiry. Boston, Massachusetts, USA: Allyn \& Bacon.

Corbin, J. \& A. Strauss 2008. Basics of Qualitative Research: Techniques and Procedures for Developing Grounded Theory. $3^{\text {rd }}$ Edition. Thousand Oaks, California: Sage.

https://doi.org/10.4135/9781452230153

Davies, J. 2010. Introduction: Emotions in the Field. In Davies, J. \& D. Spenser (eds): Emotions in the Field: The Psychology and Anthropology of Fieldwork Experience. Palo Alto, California: Stanford Press.

Forgasz, R. \& A. Clemans 2014. Feeling: Feminist: A Self-Study of Emotion as a Feminist Epistemology in Education Practice. In Taylor, M. \& L. Coia (eds): Gender, Feminism, and Queer Theory in the Self-Study of Teacher Education Practices. Boston, Massachusetts: Sense Publishers. https://doi.org/10.1007/978-94-6209-686-8_5

Goleman, D. 1995. Emotional Intelligence. New York, NY: Bantam Books. Griffiths, M., L. Bass, M. Johnston, \& V. Perselli 2004. Knowledge, Social 
Justice, and Self-Study. In Loughran, J.J., M.L. Hamilton, V.K. LaBoskey \& T. Russell (eds): International Handbook of Self-Study of Teaching and Teacher Education Practices. Dordrecht, The Netherlands: Kluwer Academic Publishers.

https://doi.org/10.1007/978-1-4020-6545-3 17

Hamilton, M.L. \& S. Pinnegar 2015. Knowing, Becoming, Doing as Teacher Educators: Identity, Intimate Scholarship, Inquiry. United Kingdom:

Emerald. https://doi.org/10.1108/S1479-368720140000026035

Jaggar, A.M. 1989. Love and Knowledge: Emotion in Feminist

Epistemology. In Jaggar, A. \& S.R. Bordo (eds): Gender/ Body/ Knowledge: Feminist Reconstructions of Being and Knowing. New Brunswick, New Jersey: Rutgers University Press.

https://doi.org/10.1080/00201748908602185

Kuzmic, J.J. 2014. Disturbing Masculinities: Epistemology, Outlaw Emotions, and the Gendered Self in Self-Study Research. In Taylor, M. \& L. Coia (eds): Gender, Feminism, and Queer Theory in the Self-Study of Teacher Education Practices. Boston, Massachusetts: Sense Publishers. https://doi.org/10.1007/978-94-6209-686-8 6

LaBoskey, V.K. 2004. The Methodology of Self-Study and its Theoretical Underpinnings. In Loughran, J.J., M.L. Hamilton, V.K. LaBoskey \& T. Russell (eds.): International Handbook of Self-Study of Teaching and Teacher Education Practice. Volume 1. The Netherlands: Springer. https://doi.org/10.1007/978-1-4020-6545-3_21

Labov, W. 1997. Some Further Steps in Narrative Analysis. Journal of Narrative \& Life History 7,1 - 4: 395 - 415.

https://doi.org/10.1075/jnlh.7.49som

Lawrence, R.L. 2012. Coming Full Circle: Reclaiming the Body. New Directions for Adult and Continuing Education 134, Summer: 71 - 78. https://doi.org/10.1002/ace.20019

Luttrell, W. 2003. Pregnant Bodies, Fertile Minds: Gender, Race, and the Schooling of Pregnant Teens. New York: Routledge.

Matias, C. 2011. Paying it Forward: Mother Scholars Navigating the Academic Terrain. Paper Presented at the American Educational Research Association (AERA), New Orleans, Louisiana.

Maxwell, J. 1998. Foreword. In Jenson, J. (ed.): Mapping Social Cohesion:

The State of Canadian Research. Ottawa, Canada: Canadian Policy Research Networks Inc. 
Misra, J., J.H. Lundquist, E. Holmes \& S. Agiomavritis 2011. The Ivory Ceiling of Service Work. American Association of University Professsors. Available at: https://www.aaup.org/article/ivory-ceiling-servicework\#.XQj44PIKj-a

Pinar, W.F. 2007. A Queer Conversation Toward Sustainability. In Rodriguez, N.M. \& W.F. Pinar (eds): Queering Straight Teachers: Discourse Identity in Education. New York: Peter Lang.

Pinnegar, S. \& M.L. Hamilton 2009. Self-Study of Practice as a Genre of Qualitative Research: Theory, Methodology, and Practice. Dordrecht, The Netherlands: Springer.

https://doi.org/10.1007/978-1-4020-9512-2_4

Powell, W.W. \& J.A. Colyvas 2008. Microfoundations of Institutional Theory. In Greenwood, R., C. Oliver, K. Sahlin \& R. Suddaby (eds.): The Sage Handbook of Organizational Institutionalism. Thousand Oaks, California: Sage.

Pratt, M.G. 2000. The Good, the Bad, and the Ambivalent: Managing Identification among Amway Distributors. Administrative Science Quarterly 45,3: 456 - 493. https://doi.org/10.2307/2667106

Prus, R. 1996. Symbolic Interaction and Ethnographic Research: Intersubjectivity and the Study of Human Lived Experience. Albany, New York: SUNY Press.

Rom, N. \& O. Eyal 2019. Sensemaking, Sense-breaking, Sense-giving, and Sense-taking: How Educators Construct Meaning in Complex Policy Environments. Teaching and Teacher Education 78: 62 - 74. https://doi.org/10.1016/j.tate.2018.11.008

Ryan, T. 2005. When You Reflect are You also Being Reflexive? The Ontario Action Researcher 8, 1.

Samaras, A. \& A. Freese 2006. Self-Study of Teaching Practices. New York: Peter Lang.

Stanley, L. \& S. Wise 1993. Breaking out Again: Feminist Ontology and Epistemology. New York: Routledge.

St. Pierre, E. 2000. Poststructuralist Feminism in Education. International Journal of Qualitative Studies in Education 13,5: 477 - 515.

https://doi.org/10.1080/09518390050156422

Strom, K.J. \& A.D. Martin 2013. Putting Philosophy to Work in the Classroom: Using Rhizomatics to Deterritorialize Neoliberal Thought and Practice. Studying Teacher Education 9,3: 219 - 235. 
https://doi.org/10.1080/17425964.2013.830970

Taylor, M. \& L. Coia 2014. Addressing Gender, Feminism, and Queer Theory through Self-Study of Teacher Education Practices: A Literature Review. In Taylor, M. \& L. Coia (eds): Gender, Feminism, and Queer Theory in the Self-Study of Teacher Education Practices. Boston, Massachusetts: Sense Publishers.

https://doi.org/10.1007/978-94-6209-686-8

Taylor, M., L. Coia, T. Hopper, K. Sanford, L. Smolin \& L. Crafton 2006.

Making Collaboration Explicit in Self-Study Research in Teacher Eduction. In Fitzgerald, L.M., M.L. Heston \& D.L. Tidwell (eds): Collaboration and Community: Pushing Boundaries through Self-Study. Proceedings of the $6^{\text {th }}$ International Conference on Self-Study of Teacher Education Practices. Cedar Falls, Iowa: University of Northern Iowa.

Thomas, L. \& C. Beauchamp 2010. Understanding Agency: A Collaborative Self-Study Exploring Tensions in Teacher Education Practice and Research. In Erickson, L.B., J.R. Young \& S. Pinnegar (eds): Navigating the Public and Private: Negotiating the Diverse Landscape of Teacher Education. Proceedings of the $8^{\text {th }}$ International Conference on SelfStudy of Teacher Education Practices. Provo, Utah: Brigham Young University.

Weick, K.E. 1995. Sensemaking in Organizations. London: Sage.

Associate Professor Brianne Morettini, PhD Department of Interdisciplinary and Inclusive Education College of Education Rowan University Glassboro, New Jersey United States of America morettini@rowan.edu

Associate Professor Kathryn Luet, $\mathrm{PhD}$ Department of Language, Literacy, and Sociocultural Education College of Education

Rowan University Glassboro, New Jersey United States of America luet@rowan.edu 